\title{
PEMANFAATAN KONTRIBUSI SISWA SEBAGAI ALAT TRANSISI MENUJU PEMAHAMAN KONSEP OPERASI PECAHAN
}

\section{Gregorius Sebo Bito}

Universitas Flores Ende

Email: $\underline{\text { sebobito@.gmail.com }}$

\begin{tabular}{ll}
\hline Info Artikel & Abstract \\
\cline { 2 - 2 } $\begin{array}{l}\text { Sejarah Artikel: } \\
\text { Diterima 28Agustus 2018 }\end{array}$ & $\begin{array}{l}\text { The purpose of this study was to describes the use of student's contribution as a transition } \\
\text { tool at each level of learning the fraction operation concept. This study involved fourth } \\
\text { grade students of an elementary school in Ngada East Nusa Tenggara. The type of this } \\
\text { Disetujui 28 Nover } 2018 \\
\text { research is Design Research with three stages, namely: initial design, teaching experiment } \\
\text { and retrospective analysis. This research begins conduct a hypothetical learning trajectory } \\
\text { (HLT) of fraction operations concept. The HLT has been tested before the actual learning } \\
\text { process (ALT). The results of the retrospective analysis obtained an overview of the Actual } \\
\text { Learning Trajectory (ALT) show that the use of various student's contribution at each level } \\
\text { of learning can lead to understanding the fraction operation concept. }\end{array}$ \\
$\begin{array}{l}\text { Keywords: } \\
\text { Student contribution, Transition } \\
\text { tools, Realistic mathematics, }\end{array}$ &
\end{tabular}

tools, Realistic mathematics,

Fraction operation concept

\begin{abstract}
Abstrak
Tujuan Penelitian ini adalah untuk mengetahui gambaran penggunaan kontribusi siswa sebagai alat transisi pada setiap level belajar konsep operasi pecahan. Penelitian ini melibatkan siswa kelas IV sebuah Sekolah Dasar di Ngada Nusa Tenggara Timur. Jenis Penelitian ini adalah Design Research yang terdiri dari tiga tahap, yaitu desain awal, eksperimen pengajaran dan analisis retrospektif. Penelitian ini diawali dengan membuat alur belajar hipotetik (Hyphotetical Learning Trajectory/HLT) konsep operasi pecahan. HLT konsep operasi pecahan telah diujicoba sebelum pelaksanaan pembelajaran yang sesungguhnya. Melalui analisis retrospektif diperoleh gambaran tentang alur belajar sebenarnya (Actual Learning Trajectory/ALT) dari proses belajar konsep operasi pecahan yang merupakan hasil menjalankan HLT. Hasil analisis retrospektif menunjukkan bahwa penggunaan berbagai bentuk kontribusi yang diberikan siswa pada setiap level belajar dapat bermuara pada pemahaman konsep operasi pecahan.
\end{abstract}

(C) 2018 Universitas Muria Kudus 
Bito, Gregorius Sebo

PEMANFAATAN KONTRIBUSI SISWA SEBAGAI ALAT TRANSISI MENUJU PEMAHAMAN ... REFLEKSI EDUKATIKA : Jurnal Ilmiah Kependidikan, Nomor 9, Volume 1, Desember 2018, hlm. 90-100

\section{PENDAHULUAN}

Pembelajaran matematika diharapkan dapat mengimplementasikan inti dari filsafat pendidikan yaitu mengaktualisasikan ketiga dimensi kemanusiaan paling dasar yang ditunjukan dengan capaian pembeajaran dari sisi afeksi (sikap), kognisi (pengetahuan) dan psikomotorik (keterampilan). Keberhasilan implementasi ketiga dimensi tersebut dapat dilakukan dengan asesemen pengukurnya secara holistik. Sisi afeksi dapat diukur dari sikap spiritual dan sosial guna pembentukan karekter peserta didik; sisi kognisi berhubungan kemampuan pengetahuan faktual, konseptual, prosedural dan metakognisi; sedangkan sisi psikomotorik dapat diukur dari capaian pembelajaran berupa ketrampilan, aplikasi pengetahuan dan kemajuan kualitas pekerjaan siswa (Kemendiknas, 2016).

Peluang akan harapan untuk penekanan terhadap ketiga dimensi seperti tersebut di atas menjadi semakin besar manakala Ujian Nasional tidak lagi menjadi satu-satunya penentu kelulusan siswa. Diberlakukannya Kurikulum 2013 diharapkan sebagai jawaban atas tuntutan untuk mengimplementasikan pembelajaran yang mengembangkan berbagai potensi peserta didik pada ketiga dimensi kehidupan manusia. Pendidik yang baik seyogianya memiliki kemampuan mengenali potensi peserta didiknya dengan baik, sehingga bantuan pendidik terhadap peserta didiknya lebih terararah dan bermanfaat bagi pengembangan potensi perta didiknya (Dardiri, 2015:1).

Aspek penting dari dimensi kognitif adalah siswa dapat menggali dan mengembangakan pengetahuan. Pengetahuan matematika umumnya merupakan pengetahuan terkait dengan objek matematika baik berupa fakta, operasi, relasi, konsep maupun prinsip. Objek-objek matematika ini bersifat abstrak sehingga merupakan objek mental (Soedjadi, 2000:15), oleh karenanya, belajar matematika merupakan kegiatan mental (Hudoyo, 1988:3).

Karena matematika merupakan seperangkat aktivitas atau kegiatan mental maka Carpenter \& Lehrer (1999) mengidentifikasi lima bentuk aktivitas mental yang harus diperhatikan guru untuk membentuk pemahaman matematika siswa seperti: (1) mengkonstruksi hubungan, (2) memperluas dan mengaplikasikan pengetahuan matematika, (3) merefleksikan pengalaman belajar yang diperoleh, (4) mengkomunikasikan apapun yang telah diketahui, dan (5) mengembangkan atau mengkonstruksi pengetahuan (obyek) matematika secara mandiri. Inti dari pendapat Carpenter dan Lehrer tersebut adalah bahwa agar pembelajaran matematika dapat bermakna bagi siswa maka tidak boleh tidak guru harus melibatkan siswa dalam keseluruhan tahapan pembelajaran dengan aktivitas aktivitas berpikir.

Segala usaha terencana guna melibatkan siswa dengan aktivitas berpikir dalam pembelajaran merupakan gagasan dasar dari konstruktivisme. Secara umum, konstruktivisme menuntut siswa terlibat penuh secara aktif dalam proses belajar matematika baik bertujuan membentuk pengetahuan untuk dirinya sendiri maupun keterlibatannya untuk membantu membentuk pengetahuan orang lain (Glaserfeld, 1995; Haylock\&Tangata, 2007; Freudenthal dalam Sutarto Hadi, 2017). Tokoh konstruktivisme von Glaserfeld (1995:8) berpendapat bahwa konstruktivisme setidaknya menuntut dua hal paling mendasar, yaitu : (1) pengetahuan tidak diterima begitu saja dari sumber manapun namun pengetahuan seharusnya dibangun sendiri oleh aktivitas kognisi subyek yang belajar; dan (2) fungsi dari aktivitas kognisi adalah menyesuaikan dan membantu untuk mengorganisir beragam pengalaman subyek belajar (siswa) yang didapatkan dari kehidupan mereka sehari-hari.

Alasan dari tuntutan pandangan konstruktivisme agar siswa secara mandiri mengkonstuksi pengetahuannya adalah bahwa pengetahuan matematika tidak datang dengan sendirinya (Haylock\&Tangata, 2007: 35). Matematika juga bukanlah merupakan sesuatu yang siap pakai (ready-made mathematics) sehingga memaksa siswa menerimanya tanpa diolah dengan melibatkan aktivitas berpikir (Freudenthal, dalam Sutarto Hadi, 2017:8). Melalui pelibatan siswa dalam aktivitas berpikir untuk proses konstruksi pengetahuan diharapkan tidak menjadikan siswa menerima begitu saja (passive receivers) tanpa memahami matematika secara utuh (Freudenthal, dalam Sutarto Hadi, 2017:8).

Salah satu dari dua hal mendasar tentang konstruktivisme menurut Glaserfeld di atas adalah pentingnya siswa mengorganisir pengalamannya di dunia nyata dalam aktivitas kognisinya guna pembentukan pengetahuan baru. Pengalaman atau pengetahuan (lama) siswa sangat penting dalam proses pemerolehan pengetahuan baru (Freudenthal dalam van den Heuvel-Panhuizen, 1996; Gravemeijer,1996; Gravemeijer, 1999; Wijaya, 2012; Sutarto Hadi, 
2017) sehingga jika pembelajaran matematika tidak menyentuh pengalaman siswa maka siswa akan merasa sulit untuk belajar matematika. Freudenthal meyakini bahwa siswa tidak akan mengingat dan tidak dapat menggunakan matematika dalam kehidupannya jika matematika tidak diajarkan dengan memulainya dari pengalaman siswa sendiri.

Pernyataan Hans Freudenthal ini dikutip oleh van den Heuvel-Panhuizen (1996:12) bahwa:" when children learn mathematics in an isolated fashion, divorced from experienced reality, it will be quickly forgotten and they will not be able to be apply it". Keadaan dimana siswa tidak lama mengingat matematika yang dipelajari dan mengaplikasikannya maka kondisi inilah yang menyebabkan siswa sulit belajar matematika. Keadaan ini disebabkan karena guru memaksakan siswa agar cepat mencapai matematika formal (Wijaya, 2012:31).

Tuntutan agar siswa cepat mencapai level matematika formal turut berkontribusi pada tidak bermaknanya konsep matematika yang dipelajari bagi siswa. Siswa terlihat mahir untuk menghafalkan materi matematika (rote memorization) namun tidak memiliki pemahaman konseptual (conceptual understanding) yang memadai terkait suatu konsep matematika yang mereka pelajari (Kennedy, Tipps \& Johnson, 2008). Untuk itu, diperlukan pembelajaran matematika yang memposisikan matematika sebagai bagian dari keseharian siswa dengan cara menyajikan matematika yang abstrak dan formal dalam bentuk yang paling mudah dipahami (Wijaya, 2012:31). Selain itu, kesulitan belajar matematika dapat terjadi karena siswa merasakan adanya kesenjangan antara pengalaman hidup sehari-hari dan materi matematika yang akan dipelajari (Gravemeijer, 1999:155).

Pembelajaran matematika yang dilaksanakan secara tidak kontekstual (dekontekstual) yaitu pembelajaran yang tidak menyentuh pengalaman siswa (konteks) akan menyebabkan konsep matematika cepat dilupakan siswa (Wijaya, 2012:31). Oleh karenanya, guru hanya perlu menyediakan konteks-konteks (Sutarto Hadi, 2017:23) yang mengandung pengetahuan matematis informal untuk dimatematisasi menjadi pengetahuan matematika formal. Melalui pembelajaran matematika bermakna diharapkan hasil belajar matematika siswa lebih optimal termasuk membentuk sikap positif terhadap matematika.
Banyaknya peneliti memberikan alasan mengapa kemampuan matematika siswa tidak sesuai dengan harapan atau standar yang ditetapkan (Zulkardi, 2007; Marpaung, 2001; Soedjadi, 2000; Soedjadi dalam Ahmad Fauzan, 2003; Fauzan, 2003; Noyes dalam Wijaya, 2012). Zulkardi (2007) memaparkan faktorfaktor yang menyebabkan rendahnya hasil belajar siswa, yaitu: (1) kandungan kurikulum yang padat, (2) kandungan materi pada buku yang digunakan dirasakan terlalu banyak dan sulit bagi siswa, (3) metode pembelajaran yang cenderung kuno dan monoton, (4) penggunaan media pembelajaran yang kurang efektif, dan (5) evaluasi yang buruk.

Alasan lainnya dikemukakan Marpaung (2001) bahwa proses pembelajaran selama ini tidak terpusat pada siswa dan tidak realistik, yaitu guru aktif menerangkan, siswa hanya mengikuti dan mendengar materi yang dijelaskan oleh guru. Pemahaman yang diperoleh siswa hanya bersifat instrumental, dimana siswa hanya mampu menggunakan rumus-rumus matematika untuk menyelesaikan soal seperti yang ditunjukkan guru. Siswa tidak memahami cara perolehan dan alasan dari penggunaan rumus tersebut. Pendekatan non realistik ini menjadikan siswa sebagai penghafal rumus-rumus tanpa pemahaman yang memadai akan perolehan rumus matematika dan penggunaannya. Akibatnya pencapaian siswa dalam pembelajaran matematika dengan pendekatan yang non realistik ini relatif rendah dan tidak mengalami peningkatan yang berarti.

Menurut Soedjadi (Ahmad Fauzan, 2003:1), padatnya kurikulum serta sulitnya materi pelajaran disebabkan karena kurikulum hanya terfokus pada pengetahuan faktual. Selain itu, keterkaitan antar topik matematika dalam kurikulum tidak tergambar jelas, disajikan terlalu teoritis dan mekanistik (hampir tidak ada aplikasi matematika dalam kehidupan siswa)(Ahmad Fauzan (2003:1). Mekanistik menurut Soedjadi (2000:1) adalah bahwa pembelajaran matematika di sekolah masih mengikuti kebiasaan dengan urutan: menerangkan rumus, memberikan contoh contoh dan memberikan latihan soal.

Urutan pembelajaran seperti ini sangat pragmatis dimana siswa tidak dilatih untuk berpikir matematis atau melakukan matematika tetapi hanya dilatih untuk melakukan perhitungan matematis seperti yang dinyatakan oleh Andrew Noyes (2007) dalam Wijaya (2012:5) bahwa: "many children are trained to do mathematical calculations rather than being 
Bito, Gregorius Sebo

PEMANFAATAN KONTRIBUSI SISWA SEBAGAI ALAT TRANSISI MENUJU PEMAHAMAN ... REFLEKSI EDUKATIKA : Jurnal Ilmiah Kependidikan, Nomor 9, Volume 1, Desember 2018, hlm. 90-100

educated to think mathematically". Dengan kata lain, dalam pembelajaran matematika di kelas yang aktif adalah gurunya, siswa kurang diberi kesempatan untuk mengembangkan pengetahuannya.

Alasan-alasan seperti yang telah dipaparkan di atas yang melatarbelakangi diterapkannya Pendekatan Pendidikan Matematika Realistik (PMR) yang hingga saat ini telah memasuki dua dekade di Indonesia (Sembiring, Hoogland \& Dolk, 2010). PMR menekankan pentingnya aktivitas kognisi siswa dalam pembelajaran matematika. Setiap siswa dituntut untuk berkontribusi menemukan sendiri konsep matematika melalui proses matematisasi (Sutarto Hadi, 2017:8) yaitu dimulai dari penyelesaian masalah matematika yang terkait dengan konteks sampai pada pemahaman matematika yang lebih formal. Dalam proses inilah terjadi transisi kepemilikan konsep matematika dari bentuk yang paling konkrit (matematika informal) ke bentuk yang paling abstrak (matematika formal).

Dalam pembelajaran matematika dengan pendekatan PMR, siswa diharapkan dapat menghubungkan sendiri pengalaman atau pengetahuan informal dengan pengetahuan formal yang abstrak. Guru hanya berperan untuk membantu siswa secara bertahap agar dapat berpindah dari pemahaman informal menuju pemahaman yang formal. Pengetahuan yang digali tersebut akan bermanfaat jika dapat dikembangkan dengan baik dan bila mungkin, dapat menjadi pengetahuan baru. Itulah tuntutan konstruktivisme dalam pembelajaran menurut Jean Piaget yang memusatkan perhatian pada aktivitas kognisi yaitu bagaimana seorang individu menggunakan berbagai gagasan secara reflektif untuk membangun pengetahuan dan pemahaman baru (Van de Walle \& Lovin, 2006:5).

Model konstruktivisme berdasarkan gagasan Piaget menggambarkan seseorang mengorganisir pengetahuan yang telah ada (skema) melalui proses asimilasi, akomodasi dan equilibrasi untuk dicocokkan dengan pengalaman-pengalaman baru yang mereka peroleh. Selain pengembangan pengetahuan oleh seseorang secara individual, konstruktivisme juga mensyaratkan hubungan sosial dalam pembelajaran. Lev Vygotsky (1978) menekankan bahwa belajar merupakan proses interaksi sosial yang berperan penting dalam perkembangan kognisi seseorang (Haylock\&Thangata, 2007:37). Interaksi sosial pada siswa dapat melatih siswa untuk dapat berpikir dengan baik (Resnick, 1988). Prinsip-prinsip pendekatan PMR cocok dengan Teori Piaget dan Lev Vygotsky di atas.

Gravemeijer (1994:90) mengemukakan tiga prinsip utama dalam PMR, yaitu: (a) guided re-invention/progressive mathematizing, didactical phenomenology dan (c) self-developed models. Pendekatan PMR memberikan penekanan dan perhatian pada proses pemerolehan kembali (reinvention/mathematizing) sebuah konsep matematika dimulai dari tahap informal sampai pada tahap formal. Re-invention yang dilakukan oleh siswa selaras dengan karakteristik konstruktivisme dan pembelajaran berpusat pada siswa (Zuliana, 2017:152). Pada proses panjang ini siswa diperlakukan seperti layaknya para ahli dimana siswa mengalami bagaimana ketika para ahli matematika menemukan konsep matematika yang saat ini siswa pelajari. Dengan tahapantahapan seperti ini, siswa dibawa pada pengalaman seolah-olah mereka sendirilah yang baru menemukan konsep tersebut sehingga keseluruhan tahapan menuntut kontribusi dari siswa dalam usaha menemukan konsep atau pengetahuan matematika.

Untuk mengalami proses penemuan pengetahuan matematika, pertama-tama siswa diberikan soal berupa masalah kontekstual yang setiap hari mereka alami. Masalah kontekstual yang dialami siswa merupakan kontribusi awal siswa. Selanjutnya, kontribusi siswa tetap dibutuhkan ketika masalah kontekstual dimatematisasi berturut turut dengan menggunakan model terhadap situasi (model of), model untuk matematika formal (model for) sampai akhirnya tahap terakhir ketika matematika formal ditemukan (Gambar 1).

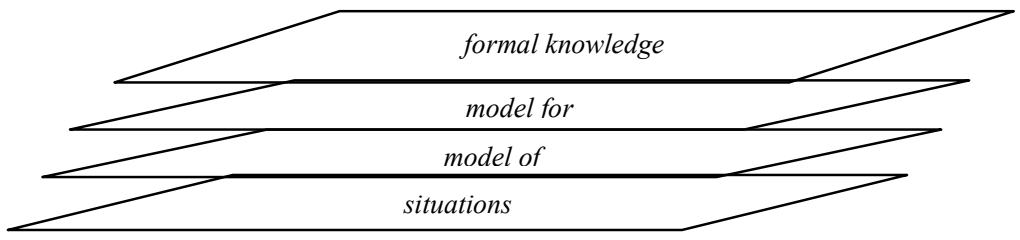

Gambar 1. Pemerolehan Pengetahuan Matematika (Sumber: Gravemeijer, 1994:100) 
Penjelasan terkait Gambar 1 di atas diuraikan oleh Gravemeijer (1994: 101) dengan empat tingkatan aktivitas yaitu: situasional, referensial, general dan formal. Tingkatan aktivitas paling dasar adalah aktivitas situasional. Pada tingkatan ini, pengetahuan matematika dan model masih sangat sederhana sesuai situasi masalah kontekstual yang digunakan. Pada tahap ini, siswa menyelesaikan masalah kontekstual tidak menggunakan matematika formal, karena pada tahap ini, mereka menyelesaikan masalah matematika secara informal sesuai dengan masalah yang diberikan.

Aktivitas selanjutnya adalah aktivitas aktivitas yang menggunakan model referensial. Aktivitas pada level ini setahap lebih abstrak dimana model yang digunakan merupakan abstraksi dari masalah (model dari masalah/ model of). Aktivitas pada tahap ini difasilitasi menggunakan alat peraga yang sesuai dengan masalah kontekstual.

Aktivitas ketiga adalah aktivitas-aktivitas yang menggunakan model yang lebih tinggi. Kalau sebelumnya pada model situasi masalah masih merujuk pada permasalahan kontekstual, maka pada ativitas ketiga sudah menggunakan model untuk (model for) permasalahan yang lebih umum bukan hanya untuk permasalahan kontekstual. Artinya, aktivitas yang menggunakan model ini sudah beranjak menuju matematika formal dimana model sudah mulai mengarah pada penyelesaian masalah secara matematis.

Tahapan aktivitas paling abstrak adalah matematika formal dimana penyelesaian masalah sudah menggunakan simbol-simbol matematika. Level aktivitas paling akhir ini adalah level aktivitas formal. Aktivitas-aktivitas yang dilakukan pada tahap akhir ini lebih ditekankan pada perumusan dan penegasan konsep matematika yang sudah dihasilkan siswa sehingga siswa sudah menggunakan simbol matematika yang formal.

Penggunaan berbagai model dalam aktivitas penemuan pengetahuan matematika sangat diperlukan karena model seperti layaknya alat matematika yang menjembatani permasalahan kontekstual dan matematika formal (Gravemeijer,1994:100). Model model ini menjembatani proses transisi dari matematika paling sederhana (matematika informal) menuju matematika formal (matematika yang abstrak). Dalam pembelajaran matematika, matematika paling sederhana adalah masalah-masalah kehidupan yang akan dipecahkan secara matematis dan masih sangat konkrit. Masalahmasalah ini ada dan atau bisa dibayangkan oleh para siswa.

Keberagaman model yang digunakan untuk proses transisi dari konkrit (masalah kontekstual), semi konkrit sampai ke model abstrak layaknya sebagai proses bermatematika yang umumnya dimulai dari keadaan yang informal sampai menjadi sesuatu yang formal. Jadi, penggunaan model menjadi tuntutan penting dalam aktivitas bermatematika (matematisasi). Model-model yang dimaksudkan di atas merupakan pemodelan yang dilakukan oleh siswa sendiri. Kontribusi individu dan kelompok dalam pengembangan model menjadi hal yang ditekankan dalam pendekatan PMR. Artinya, siswa harus senantiasa terlibat aktif baik dalam berpikir, berbicara, mendengar dan aktivitas lainnya. Pendekatan PMR merupakan pendekatan pembelajaran yang berpusat pada siswa sehingga siswa wajib berkontribusi baik secara individu dan kelompok dengan terlibat secara aktif dalam diskusi kelas, menunjukkan sikap setuju atau tidak setuju dengan solusi temannya, menanyakan alternatif pemecahan masalah, dan merefleksikan solusi-solusi itu (Bakker, 2004 dalam Rahayu, 2015).

Agar siswa memberi kontribusi pada setiap tahap pembentukan pengetahuan matematika, guru perlu merancang serangkaian aktivitas belajar secara bertahap seiring dengan model atau alat matematika yang digunakan. Dalam merancang serangkaian aktivitas tersebut, guru juga perlu mempertimbangkan segala sesuatu yang diprediksikan akan berkembang dalam pembelajaran sehingga perlu diantisipasi sejak sebelum pembelajaran berlangsung. Rancangan ini disebut dengan istilah Hypothetical Learning Trajectory (HLT). Hal ini dimaksudkan agar transisi aktivitas siswa selalu difasilitasi dengan kontribusi yang diberikan siswa sehingga siswa belajar matematika formal berdasarkan apa yang mereka hasilkan pada setiap tahapnya. Pelaksanaan segala sesuatu yang telah dirancang dalam proses pembelajaran sebenarnya akan menjadi Actual Learning Trajectory (ALT) yang dapat dipakai untuk menyusun HLT.

Artikel ini memaparkan jawaban atas rumusan masalah sebagai berikut: "Bagaimanakah bentuk kontribusi siswa yang digunakan sebagai alat transisi dalam penanaman konsep operasi penjumlahan dan pengurangan pecahan dengan pendekatan PMR?" Oleh karena itu, dalam artikel ini akan disajikan proses 
transisi pengetahuan dari tahap informal ke formal (informal-formal) operasi penjumlahan dan pengurangan pecahan yang memiliki penyebut sama menggunakan kontribusi siswa di setiap tahap aktivitas belajar matematika mulai dari role playing permasalahan kontekstual, memodelkan masalah kontekstual dengan untaian manik-manik, penggunaan garis bilangan, membuat soal cerita yang berkaitan dengan penjumlahan pecahan dan menyelesaikan soal cerita yang telah dibuat sendiri secara formal dengan menggunakan prosedur operasi penjumlahan pecahan yang mereka temukan sendiri. Gambaran hasil pembelajaran yang disajikan dalam artikel ini merupakan ALT dari pelaksanaan HLT pembelajaran operasi pecahan.

\section{METODE PENELITIAN}

Penelitian ini melibatkan siswa kelas IV SDK Bomari Langa NTT dan Guru Kelas IV. Jenis Penelitian ini adalah Design Research yang terdiri dari tiga tahap, yaitu mengembangkan desain awal, melakukan eksperimen pengajaran di kelas dan melaksanakan analisis retrospektif (Bakker, 2004). Penelitian ini dimulai dengan menyusun sebuah Hyphotetical Learning Trajectory (HLT) atau dugaan tentang alur belajar siswa yang terdiri dari: tujuan pembelajaran bagi siswa, kegiatan pembelajaran direncanakan, sumber daya yang digunakan dalam proses pembelajaran, dan dugaan tentang proses pelaksanaan pembelajaran termasuk mengantisipasi pemikiran, pemahaman siswa serta berbagai situasi yang mungkin saja dapat berkembang ketika kegiatan pembelajaran berlangsung (Gravemeijer, 2004).

HLT ini diujicoba sebelum pelaksanaan pembelajaran yang sesungguhnya. Berbagai temuan dan pengalaman yang diperoleh dalam ujicoba ini menjadi pertimbangan untuk modifikasi HLT sebelum digunakan dalam pembelajaran sebenarnya. Dalam tahap analisis retrospektif, semua data selama pembelajaran dianalisis. Hasil analisis retrospektif akan diperoleh gambaran tentang alur belajar sebenarnya sebagai hasil menjalankan HLT atau yang disebut Actual Learning Trajectory (ALT).

Hasil yang dipaparkan pada artikel ini adalah hasil analisis ulang rekaman video pembelajaran dan hasil pekerjaan siswa (analisis retrospektif) yang merupakan alur belajar sebenarnya (ALT). Makalah ini hanya memuat sebagian kecil dari ALT yaitu gambaran penggunaan kontribusi siswa sebagai alat transisi dalam pemahaman konsep operasi pecahan.

\section{HASIL DAN PEMBAHASAN}

Salah satu materi yang diajarkan di tingkat pendidikan sekolah dasar adalah materi pecahan. Tidak dapat dipungkiri, sejak lama, materi pecahan merupakan salah satu materi yang cukup sulit bagi siswa sekolah dasar maupun orang dewasa (Van Niekrek, et al, 1999; Van de Walle \& Lovin, 2006; Permatasari, Junianti \& Patahudin, 2012). Oleh karenanya, pembelajaran matematika bermakna seperti pendekatan PMR perlu diterapkan untuk mengatasi kesulitan belajar pecahan pada siswa sekolah dasar. Salah satu prinsip pendekatan PMR adalah menggunakan kontribusi siswa (Wijaya,2012; Sutarto Hadi,2017; Gravemeijer, 1994). Kontribusi berupa hasil berpikir siswa menjadi jembatan atau alat (matematika) transisi pada proses pengembangan konsep matematika mulai dari matematika informal sampai matematika formal seperti aktivitas pemodelan dalam Gravemeijer (1994).

Pecahan merupakan salah satu sub konstruk bilangan rasional dan memiliki banyak tafsiran/ interpretasi. Lamon (2012:257) menggolongkan pecahan dalam lima interpretasi yaitu: (a) sebagai perbandingan antara bagian dengan sesuatu yang utuh (part-whole comparison), (b) sebagai rasio (ratio), (c) ukuran (measure), (d) quotient, dan (e) sebagai operator. Dari kelima interpretasi pecahan tersebut, pembelajaran pecahan di sekolah dasar awalnya dimulai dengan pengenalan konsep pecahan sebagai part-whole relationship sehingga mereka memahami konsep pecahan sebagai bagian dari keseluruhan bagian yang sama besar.

Pengenalan konsep pecahan sebagai relasi antar bagian dan keseluruhan bagian (part-whole relationship) berhubungan dengan aktivitas mempartisi (partitioning) sebuah obyek menjadi beberapa bagian dengan besar yang sama. Oleh karenanya, Lamon (2012) berpendapat bahwa kemampuan mempartisi sangat penting untuk memahami pecahan karena pecahan dapat dibentuk atau dihasilkan dengan kegiatan mempartisi. Siswa SD pun telah dikenalkan dengan mempartisi/melipat benda dengan bentuk-bentuk geometri misalnya lingkaran, persegi dan persegi panjang serta bentuk-bentuk geometris lainnya. Selain itu, siswa usia sekolah dasar sangat familiar dengan aktivitas-aktivitas yang terkait dengan konteks membagi adil (fair sharing) (Fosnot\&Dolk, 2002; Van de Walle \& Lovin, 2006). Siswa bahkan memiliki pengalaman mempartisi sebuah obyek jauh 
Bito, Gregorius Sebo

PEMANFAATAN KONTRIBUSI SISWA SEBAGAI ALAT TRANSISI MENUJU PEMAHAMAN ... REFLEKSI EDUKATIKA : Jurnal Ilmiah Kependidikan, Nomor 9, Volume 1, Desember 2018, hlm. 90-100

sebelum mereka memasuki usia sekolah (Kennedy, Tipps \& Johnson, 2008). Siswa juga memiliki pengalaman membeli makanan ringan dalam bentuk rentengan (satu renteng makanan ringan di pasaran biasanya terdiri dari 10 bungkus). Pengalaman siswa ini dapat dijadikan starting point untuk pembelajaran operasi pecahan.

Aktivitas mempartisi seperti fair sharing (aktivitas membagi makanan ringan secara adil sesuai cerita yang diberikan guru) dalam permasalahan kontekstual merupakan kontribusi awal siswa yang dianggap penting untuk memulai pembelajaran konsep dan operasi pecahan. Pengalaman ini merupakan pengetahuan informal matematika terkait pecahan yang dapat memunculkan konsepkonsep spontan (spontaneus concept). Aktivitas fair sharing erat kaitanya dengan kegiatan mempartisi suatu obyek dan merupakan big ideas dalam pembelajaran konsep dan operasi pecahan (Van de Walle \& Lovin, 2006)

Pada awal pembelajaran operasi pecahan, siswa diberikan permasalahan kontekstual berupa drama pembagian (aktivitas mempartisi) serenteng makanan ringan. Kegiatan ini bertujuan untuk memberikan stimulus awal agar menyadarkan siswa bahwa pengalaman mereka membagi sesuatu secara adil berhubungan dengan konsep dan operasi pecahan. Kegiatan ini merupakan tahap awal pembelajaran untuk mengorientasikan pengalaman siswa sehari hari pada lingkungan matematika yang akan dipelajari. Salah satu contoh permasalahan kontekstual untuk pembelajaran konsep dan operasi pecahan adalah sebagai berikut.

\section{Masalah Membagi Makanan Ringan}

Pada suatu siang sepulangnya dari pasar Bajawa, ibu membawa oleh oleh berupa 1 renteng makanan ringan untuk Owyn. Siang itu Owyn langsung makan 1/5 bagian dan pada sore harinya ia menghabiskan lagi $2 / 5$ bagian. Sisanya akan diberikan pada temannya? Berapa bagiankah makanan ringan yang telah dihabiskan Owyn? Berapakah bagian makanan ringan yang diberikan Owyn pada temannya?

Dalam keseharian, siswa memiliki pengalaman seperti masalah di atas. Transisi pengetahuan diawali dengan mengorientasikan masalah secara matematis dimana, siswa diberikan satu renteng makanan ringan untuk memperagakan masalah kontekstual tersebut (di pasaran, serenteng makanan ringan anak anak biasanya berisi 10 bungkus setiap rentengnya). Orientasi masalah membagi makanan ringan secara matematis bertujuan untuk membangun kesadaran siswa bahwa pengalaman mereka sebetulnya berhubungan dengan materi matematika yang akan dipelajari. Orientasi ini juga penting untuk mengingatkan kembali aktivitas fair sharing yang pernah mereka lakukan dan menghubungkannya dengan materi pecahan yang dipelajari. Makanan ringan dalam bentuk rentengan telah dipilih sebagai alat (tools) agar siswa memiliki bayangan mental (mental imagery) akan arti pecahan sebagai hubungan antara bagian-bagian (bungkusan terpisah) dan sesuatu yang utuh (part-whole relationship).

Satu renteng makanan ringan sengaja dipilih karana gambaran utuh dari 1 renteng makanan ringan yang tidak terpisah menggambarkan bentuk persegi panjang utuh dan 10 bungkus makanan ringan yang dibatasi posisi-posisi untuk mempartisi memberikan gambaran mental (mental imagery) pada siswa pecahan-pecahan unit sebesar 1/10. Ketika siswa menyelesaikan permasalahan kontekstual di atas, kontribusi awal siswa adalah menyelesaikannya dengan menggunakan gambar gambar makanan ringan tersebut. Gambar-gambar yang dihasilkan siswa guna penyelesaian masalah adalah kontribusi awal untuk tujuan transisi bagi penggunaan gambar persegi panjang bagi pembelajaran konsep dan operasi pecahan.

Aktivitas pembelajaran dimulai dengan aktivitas situasional. Siswa mempraktikkan skenario drama yang tertulis dalam permasalahan kontekstual menggunakan model konkrit/situasional yaitu serenteng makanan ringan. Pada tingkatan ini siswa sudah memiliki pengetahuan awal terkait pengertian pecahan sebagai hubungan antara bagian-bagian dengan sesuatu yang utuh (fraction as part of a whole) serta kemampuan mempartisi sebuah obyek. Berawal dari mengalami situasi (masalah kontekstual) dalam aktivitas drama matematika, siswa dapat memodelkan masalah membagi makanan ringan dengan mempartisi, menyusun, melambangkan dan memvisualisasikan drama tersebut menggunakan alat matematika/model berupa makanan ringan yang diberikan.

Peragaan masalah yang dekat dengan keseharian siswa sangat penting dimana prinsip pertama dari pendekatan matematika realistik 
Bito, Gregorius Sebo

PEMANFAATAN KONTRIBUSI SISWA SEBAGAI ALAT TRANSISI MENUJU PEMAHAMAN ... REFLEKSI EDUKATIKA : Jurnal Ilmiah Kependidikan, Nomor 9, Volume 1, Desember 2018, hlm. 90-100

adalah penggunaan masalah kontekstual. Drama membagi makanan ringan merupakan kegiatan paling awal bagi siswa untuk mulai membuat sendiri prosedur operasi penjumlahan dan pengurangan pecahan.

Setelah orientasi lingkunan secara matematis, pada level yang lebih tinggi, siswa diminta menggunakan alat pemodelan berupa manik-manik (hitam dan putih), kartu pecahan kosong, dan senar. Manik-manik hitam dan manik-manik putih bertujuan untuk membedakan model makanan ringan yang telah dimakan dan yang belum dimakan. Kartu pecahan yang digantungkan pada untaian manik-manik membantu siswa melambangkan hasil mempartisi manik-manik menjadi beberapa bagian yang sama. Siswa diminta memodelkan situasi masalah kontekstual dengan seuntai manik-manik dan kartu pecahan. Selanjutnya siswa diminta menggambarkannya.

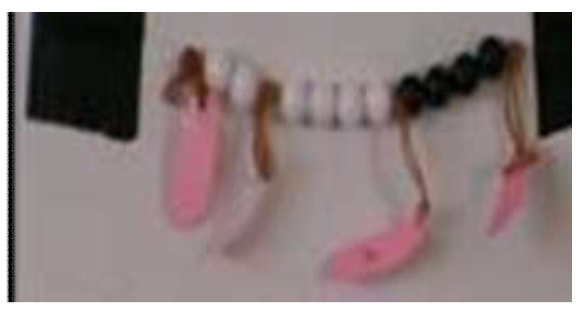

Gambar 2. Siswa memodelkan soal dalam drama menggunakan manik-manik yang digantungkan kartu pecahan.

Gambaran siswa seperti pada Gambar 2 di atas merupakan saat transisi sebelum penggunaan garis bilangan dalam operasi penjumlahan dan pengurangan pecahan. Selanjutnya, siswa menggambarkan untaian manik-manik dan kartu pecahan sebagai berikut:

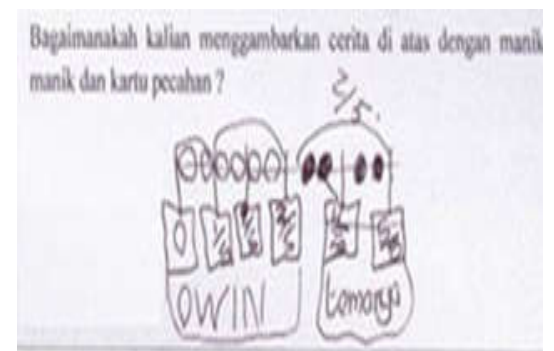

Gambar 3. Siswa menggambarkan untaian manik-manik dan kartu pecahan sesuai skenario dalam drama.

Gambar untaian manik-manik yang digantungkan garis bilangan merupakan bayangan mental dari garis bilangan. Gambar 3 di atas merupakan bentuk kontribusi penting siswa yang berguna bagi proses pengenalan garis bilangan untuk operasi penjumlahan dan pengurangan pecahan. Penggunaan model untaian manik-manik dapat menjadi jembatan menuju pada operasi penjumlahan dan pengurangan menggunakan garis bilangan. Kontribusi siswa seperti pada Gambar 2 dan Gambar 3 digunakan untuk membimbing siswa melakukan operasi penjumlahan dan pengurangan pecahan menggunakan garis bilangan pada level general.

Pada level general, garis bilangan digunakan untuk membimbing siswa menuju kesimpulan terkait presedur formal operasi penjumlahan dan pengurangan pecahan. Penggunaan garis bilangan kosong (empty number line) juga dimanfaatkan pada level general. Kontribusi siswa selanjutnya adalah dengan difasilitasi soal, siswa diminta untuk melengkapi garis bilangan kosong dan menggambarkan garis bilangan.

Level aktivitas keempat yaitu level formal. Aktivitas siswa pada level ini tidak menggunakan garis bilangan tetapi untaian bilangan pecahan. Siswa diminta membuat soal cerita yang sesuai dengan untaian bilangan pecahan yang diberikan dan menyelesaikannya secara formal. Representasi dari untaian manikmanik sebagai model dari situasi (drama matematika) ditransformasikan pada garis bilangan sebagai model untuk penalaran matematika yang lebih formal. 
Bito, Gregorius Sebo

PEMANFAATAN KONTRIBUSI SISWA SEBAGAI ALAT TRANSISI MENUJU PEMAHAMAN ... REFLEKSI EDUKATIKA : Jurnal Ilmiah Kependidikan, Nomor 9, Volume 1, Desember 2018, hlm. 90-100

Dari uraian di atas, dapat dilihat bahwa kontribusi siswa menjadi sesuatu yang digunakan dalam proses transisi pada setiap level menuju penemuan prosedur operasi penjumlahan dan pengurangan pecahan dari informal (situasional) sampai pada matematika formal (level formal). Penggunaan kontribusi siswa dalam setiap proses transisi dapat digambarkan pada Tabel 1 berikut.

Tabel 1. Transisi Belajar Penjumlahan Pecahan menggunakan Kontribusi Siswa

Aktivitas yang dirancang Guru
berdasarkan kontribusi siswa
Pengalaman siswa
Pada suatu siang sepulangnya dari
pasar Bajawa, ibu membawa oleh oleh
berupa 1 renteng makanan ringan
untuk Owyn. Siang itu Owyn langsung
makan 1/5 bagian dan pada sore
harinya ia menghabiskan lagi 2/5
bagian. Sisanya akan diberikan pada
temannya? Berapa bagiankah
makanan ringan yang telah dihabiskan
Owyn? Berapakah bagian makanan
ringan yang diberikan Owyn pada
temannya?

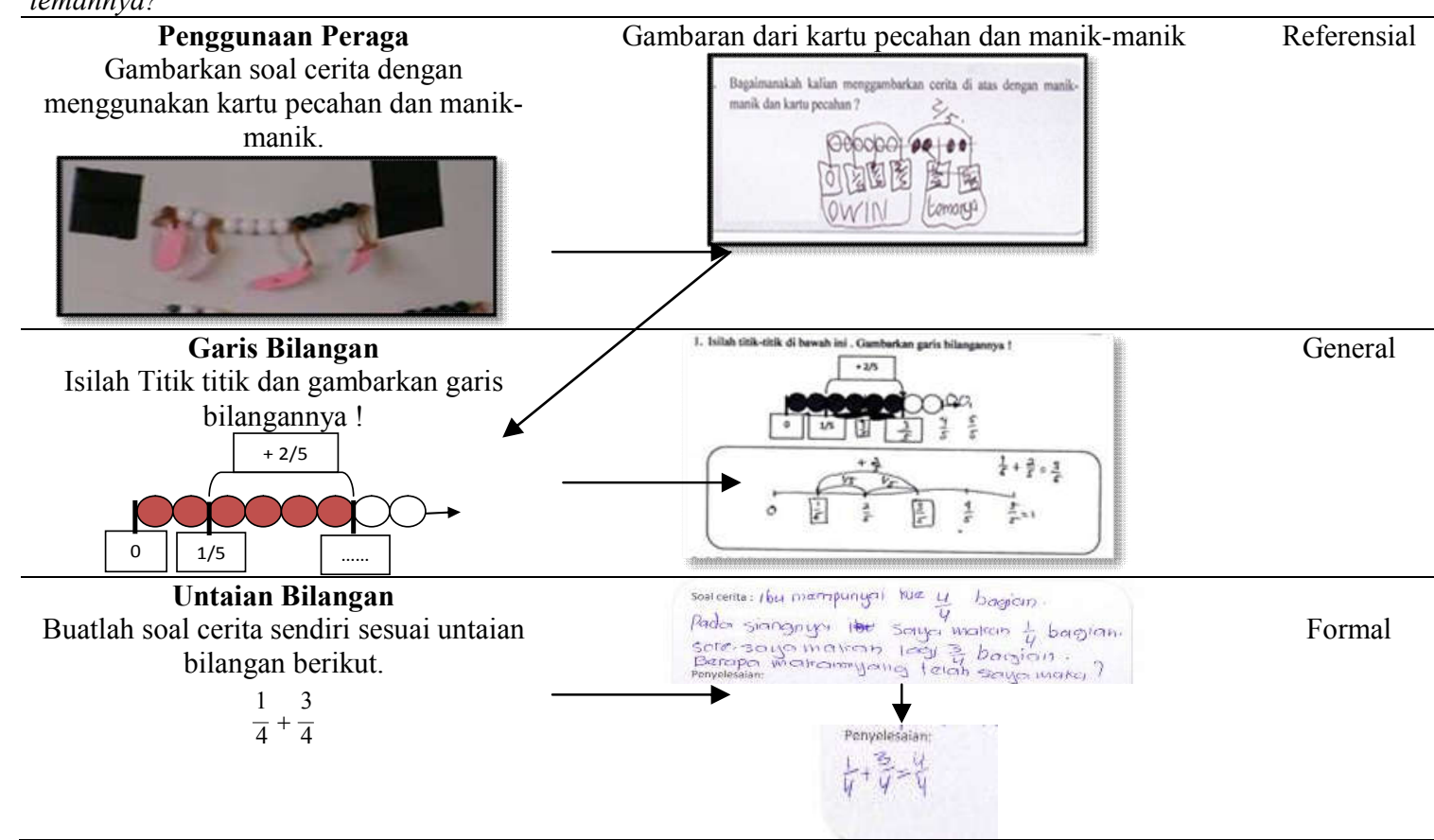

Siswa memiliki pengalaman sehari-hari yang berhubungan dengan aktivitas partisi (partitioning). Aktivitas mempartisi merupakan salah satu aktivitas paling fundamental dalam pembelajaran pecahan seperti yang dikemukakan oleh Lamon (2012) selain mencari kesamaan pecahan dan menggunakan ukuran pecahan yang sama dalam penjumlahan dan pengurangan pecahan.
Pengalaman siswa dalam mempartisi sebuah obyek atau sekumpulan obyek diskrit dipandang sebagai kontribusi awal yang penting dan digunakan guru dengan membuat permasalahan kontekstual (drama membagi makanan ringan). Pengalaman siswa tersebut dijadikan transisi untuk menyelesaikan masalah kontekstual melalui aktivitas membagi makanan ringan. Penggunaan masalah kontekstual 
Bito, Gregorius Sebo

PEMANFAATAN KONTRIBUSI SISWA SEBAGAI ALAT TRANSISI MENUJU PEMAHAMAN ... REFLEKSI EDUKATIKA : Jurnal Ilmiah Kependidikan, Nomor 9, Volume 1, Desember 2018, hlm. 90-100

merupakan prinsip prinsip pertama dari Pendekatan PMR.

Dari permasalahan kontekstual yang diberikan pada awal pembelajaran, siswa dituntut untuk memberikan kontribusi lain yaitu melakukan skenario "membagi makanan ringan" yang diberikan. Guru menggunakan pengalaman siswa saat melakukan proses partisi makanan ringan dengan meminta siswa untuk menggambarkan skenario dalam bentuk gambar. Kontribusi siswa dalam memvisualisasikan skenario dalam bentuk gambar (model of situation) merupakan kontribusi penting untuk transisi menuju penggunaan model gambar dari penjumlahan pecahan.

Prinsip kedua dari PMR adalah penggunaan keberagaman model dalam PMR. Aktivitas pemodelan dalam PMR selanjutnya adalah aktivitas referensial dimana siswa memodelkan skenario menggunakan manikmanik. Aktivitas siswa memodelkan skenario "membagi makanan ringan" dengan menggunakan manik-manik merupakan kontribusi penting untuk transisi menuju penggunaan garis bilangan dalam menyelesaikan operasi penjumlahan dan pengurangan pecahan.

Penggunaan garis bilangan bertujuan untuk memodelkan masalah dalam bentuk yang lebih abstrak (model for). Tahap terakhir adalah matematika formal, dimana untaian bilangan digunakan untuk memfasilitasi siswa menentukan prosedur penjumlahan bilangan pecahan. Pada fase ini, siswa diharapkan dapat menerapkan prosedur penjumlahan pecahan formal dalam situasi lain, yaitu soal cerita operasi pecahan yang dihasilkan sendiri oleh masing-masing siswa.

Prinsip konstrutivisme terjadi ketika siswa menyelesaikan sendiri masalah kontekstual sampai menyelesaikan operasi penjumlahan dan pengurangan pecahan secara formal. Proses pembelajaran dengan pendekatan PMR memberikan kesempatan kepada siswa untuk memberikan kontribusi dalam setiap tahap aktivitas pemodelan untuk menemukan sendiri pengetahuan matematika berupa prosedur operasi penjumlahan dan pengurangan pecahan. Pengetahuan matematika baru yang telah dibentuk sendiri oleh siswa digunakan lagi untuk menyelesaikan masalah sejenis pada situasi yang berbeda. Siswa dapat membuat permasalahan terkait operasi penjumahan dan pengurangan pecahan dan menyelesaikannya dengan prosedur operasi yang telah siswa temukan sendiri.

\section{SIMPULAN}

Prinsip konstruktivisme dalam pembelajaran matematika menginginkan siswa tidak dibiarkan begitu saja belajar tanpa tahaptahap yang direncanakan secara matang. Menemukan sendiri pengetahuan matematika perlu dibimbing dengan berbagai sumber daya sebagai alat pembelajaran yang mendukung proses matematisasi baik matematisasi vertikal maupun horisontal. Segala sumber daya yang dimaksud untuk memfasilitasi siswa "menemukan sendiri dalam bimbingan" sumber daya dan guru. Pendekatan PMR menekankan pada proses guided reinvention (penemuan terbimbing) dimana guru berperan memberi bantuan terbatas yang dibutuhkan siswa untuk belajar matematika dengan melakukan matematika.

Alat matematika (model) yang digunakan guru dalam proses pengembangan konsep matematika pada suatu level dapat disesuaikan dengan kontribusi siswa pada level tersebut. Kontribusi siswa pada suatu level akan digunakan untuk memfasilitasi siswa belajar pada level yang lebih tinggi.Transisi pengetahuan matematika siswa dari level yang lebih rendah ke level yang lebih tinggi selalu menggunakan kontribusi siswa pada level sebelumnya.

Pemanfaatan cara berpikir siswa (kontribusi siswa) dalam pembelajaran matematika sangat penting. Kontribusi siswa yang relevan dengan pengalaman kesehariannya dan dengan obyek matematika akan meningkatkan kepercayaan diri siswa dalam belajar matematika. Guru hanya perlu menyelaraskan berbagai bentuk kontribusi yang muncul dalam pembelajaran matematika sebagai alat transisi untuk menjembatani pengetahuan informal (pengalaman dengan fenomena matematis) dan matematika formal yang abstrak.

\section{DAFTAR PUSTAKA}

Ayunika, E. P. S., Junianti, D., \& Patahudin, S. M. 2012. Early Fractions Learning of $3^{\text {rd }}$ Grade Students in SD Laboratorium UNESA. IndoMS. J.M.E Vol. 3 No. 1, pp. 17-28.

Carpenter, T \& Lehrer, R. 1999. Teaching \& Learning Mathematics with Understanding, dalam E. Fennema \& T. Romberg (eds), Mathematical Classroom that Promote 
Understanding. Mahwah, NJ: Lawrence Erlbaum Associates.

Dardiri, A. 2015. Peran Filsafat Pendidikan dalam Mengembangkan Potensi Peserta Didik Untuk Membangun Generasi yang Berkarakter. Prosiding Seminar Nasional Pendidikan Dasar, PGSD Uniflor Ende, 17 Oktober 2015.

Kemediknas. 2016. Panduan Penilaian Untuk Sekolah Dasar (SD), Edisi Revisi. Jakarta: Direktorat Pembinaan Sekolah Dasar, Dirjen Pendidikan Dasar dan Menengah Kemendiknas.

Fosnot, C.T. \& Dolk, M. 2002. Young Mathematicians at Work: Constructing Fraction, Decimals, and Percents. Portsmouth: Heinemann.

Gravemeijer, K,. 2004. Local Instruction Theories as Means of Support for Teachers in Reform Mathematics Education. Mathematical Thinking and Learning, 6(2), 105-128.

Gravemeijer, K.P.E 1994. Developing Realistic Mathematics Education. Utrecht: Freudenthal Institute, Netherlands.

Haylock, D \& Thangata, F. 2007. Key Concepts in Teaching Primary Mathematics. London: Sage Publications.

Hudoyo, H. 1988. Mengajar Belajar Matematika. Jakarta: Direktorat Pendidikan dan Kebudayaan, Direktorat Jenderal Pendidikan Tinggi, Proyek Pengembangan Lembaga Pendidikan Tenaga Kependidikan.

Kennedy, L.M., Tipps, S. \& Johnson, A. 2008. Guiding Children's Learning of Mathematics. Belmont: Thomson Wadsworth.

Lamon, S.J. 2012. Teaching Fractions and Ratios for Understanding: Essential Content Knowledge and Instructional
Strategies for Teachers ( $3^{\text {rd }}$ Edition). NY: Routledge.

Rahayu, R. 2015. Faktor-Faktor Yang Mempengaruhi Kepercayaan Diri Siswa Kelas VIII dalam Menyelesaikan Masalah Matematika pada Model PMRI. Refleksi Edukatika: Jurnal Ilmiah Kependidikan, 5 (2).

Resnick, L. B. 1988. Treating mathematics as an ill-structured discipline, dalam R. I. Charles \& E. A. Silver (Eds.), The teaching and assessing of mathematical problem solving (pp. 32-60). Hillsdale, NJ: Lawrence Erlbaum Associates.

Sembiring, R., Hoogland, K., Dolk, M. 2010. A Decade of PMRI in Indonesia. Utrecht: Tim PMRI.

Sutarto Hadi. 2017. Pendidikan Matematika Realistik: Teori, Pengembangan dan Implementasinya. Jakarta: Rajawali Pers.

Van de Walle, J.A \& Lovin, L.H. 2006. Teaching Student-Centered Mathematics Grade 3-5 (The Van de Walle Professional Mathematics Series Volume Two). New York: Pearson Education, Inc.

Van Niekrek, T., 1999. Successes and obstacles in the development of grade 6 learners' conceptions of fractions. Paper presented at the 5th Annual Congress of the Association for Mathematics Education of South Africa (AMESA), Port Elizabeth.

Von Glaserfeld, E. 1995. Radical Construktivism. London: Falmer Press.

Wijaya, A. 2012. Pendidikan Matematika Realistik: Suatu Alternatif Pendekatan Pembelajaran Matematika. Yogyakarta: Graha Ilmu.

Zuliana, E. 2017. Desain Siputmatika dan Rancangan Lintasan Belajar Siswa Sekolah Dasar pada Materi Simetri Putar. Refleksi Edukatika: Jurnal Ilmiah Kependidikan, 7 (2) 